\title{
Platform Work as an Important New Form of Labour in Croatia
}

\author{
Predrag Bejakovic $\hat{c}^{*}$ \\ Peter Gladoić Håkansson**
}

\begin{abstract}
Recently, developments in digital technology have fuelled the emergence of online platforms that match the supply and demand of goods and services. In most European countries, platform work is still small, but it is strongly and rapidly developing. The types of work offered through platforms are ever-increasing, as are the challenges for existing regulatory frameworks. However, we still know very little about platform work, and there is a lack of understanding of the challenges regarding the working conditions and social protection of platform workers. Employers' and employees' organizations so far have no sharp solutions, and the Croatian government seems to prioritize other political issues. Although stakeholders are usually informed, the discussion about regulating platform employment and its possible widespread persistence has not started yet in the majority of EU countries. Particular attention in this paper is dedicated to the situation and determinants of platform work in Croatia.
\end{abstract}

Keywords: digital technology; platform work; labour market; EU; Croatia

JEL classification: J48, J51, J81, O15

\section{Introduction}

The economic and social impact of new technologies has always been contradictory. On the one hand, new technologies are a vital factor of economic development and social progress. On the other hand, new technology solutions can tear existing socioeconomic fibres and the organizational, cultural, and institutional mechanisms that sustain them. More than 30 years ago, Melvin Kranzberg (1986) formulated his first

\footnotetext{
* Predrag Bejaković is a senior researcher, Institute for Public Finance, 10000 Zagreb Smičiklasova 21, Croatia, Phone: +385 1 488-6455, predrag.bejakovic@ijf.hr

*** Peter Gladoić Håkansson is associate professor, Institute for Urban Research, Malmö University, 20506 Malmö, Sweden, Phone +46 40 040-6658227, peter.hakansson@ mau.se
} 
law of technology: "technology is neither good, nor bad; nor is it neutral." He uses the example of DDT, a pesticide shown to have adversely affected the food chain. This pesticide was removed from the US market, while in India it remained in production because it saved lives in the developing and poor country. This emphasizes the point that context makes all the difference in evaluating technology. Kranzberg (1986) also stresses the historian's role of analysing the short-term versus the long-term impact and what might have been versus what actually happened.

Although technical change has always been present in human history, its pace as well as its economic and social consequences are non-linear. Change often takes place in "jumps", which have been considered as "punctuated equilibrium" (Pierson, 2004; Thelen, 2004). Jumps may occur due to externally driven events like war, revolution, or different forms of crises. From a Schumpetarian perspective, a structural crisis is the start of something new; it allows new technology to challenge old technology. New paths into new technology challenge production systems, power hierarchies, and paradigms (Schumpeter, [1942] 1992).

The recent increase in digitalization and, particularly, the speed of its expansion - including the development of Artificial Intelligence, the proliferation of broadband Internet, the swift development of the Internet, and the widespread application of platform economy - challenges the old way of organizing work. This also encompasses how tasks are distributed across the workforce, the type of jobs that will be required, and the possibility of new technology solutions to substitute human work. One of those new technologies are digital platforms that enable connection between suppliers and demanders in various countries. This emerging phenomenon has affected a notable number of workers, and it provides them with an important source of income. Many countries have experienced a strong growth of this type of work in recent years (Pesole et al., 2018).

Online platform work is one form of the sharing economy model - driven by technology, economic crisis, lowered consumer trust in the classical corporate world, changing consumption patterns, and environmental concerns. Undoubtedly, it has significantly changed the way people organize their work and earn their living. Valant (2016) underlines that it "empowers consumers to capitalise on their property and skills, by using them more efficiently, and gives them an opportunity for micro-entrepreneurship and for reducing the total cost of ownership of their property."

Online platform work usually refers to all labour provided through, on, or mediated by online platforms (Garben, 2017). It features a wide scope of working arrangements and relationships - such as informal work, casual work, dependent self-employment, or work from home in various sectors. Consequently, there are serious challenges for existing regulatory frameworks. The absence of a common understanding of platform work by experts, policymakers, social partners, and other stakeholders across the EU results in a lack of comparable data, which tends to confuse the policy debate. Recent studies often try to define, classify, and quantify platform workers, but there 
are no in-depth assessments that would enable a detailed understanding of the challenges, working conditions, and social protection as well as the broader social impact of platform work.

The next section offers a definition of platform work. The third section is dedicated to responding to the complex challenges of platform work, and the fourth section provides an analysis of the situation in Croatia. The article ends with concluding remarks. For the obtained insights, the empirics are based on interviews with people active in platform work.

\section{What is Platform Work?}

Platform work is a new form of employment that emerged in Europe about a decade ago. While it is still small in scale - workers are estimated to be less than $10 \%$ of all employed workers - it is growing persistently (de Groen et al., 2018). New platforms are constantly emerging, changing, and broadening their business models or disappearing. However, although it is relatively rare, some platforms have gained a solid position and longevity. According to Eurofound (2018a, 2018b), platform work is a model of employment that uses an online platform to enable individuals or organizations to access services provided by individuals or organizations in exchange for payment.

Platform work mainly involves paid work organized through an online platform between three parties - the online platform, the client, and the worker - with the aim to carry out specific tasks. The work is often divided into tasks and outsourced or contracted out. Since the main traded good is labour, rather than materials or capital, sales platforms (such as eBay) or platforms providing access to accommodation (for example, DigitalGuest and Airbnb) are not included in this definition. Additionally, non-commercial transactions like social media (such as LinkedIn), networking, and volunteering are not considered platform work. Consequently, this paper and the literature review focus on online platforms designed for the supply of and demand for paid labour.

Platform work has opened up innovative possibilities for new start-ups and employees in need of additional revenue - thereby decreasing prices, improving accessibility to services, and broadening the choice for consumers. However, such platform work model has also shaken up already highly regulated traditional business models and raised questions regarding a level playing field for all market players, liability, quality of service, safety, and consumer protection (Valant, 2016).

From a legal perspective, platform work does not represent a distinct or separate form of employment in most countries (for example, for Germany, see de Groen et al, 2018; for Sweden, see Sjöberg, 2018). Therefore, income earned from platform work does not constitute a separate income category for taxation purposes. There 
are no official data regarding the extent of platform work and frequency of its use in most EU countries. There seems to be a consensus that platform work is a relatively marginal phenomenon on the EU labour market, but there are indications that it has increased in importance relatively rapidly in recent years.

\section{Challenges of Platform Work and Related Responses}

In response to the complex challenges of platform work, the EU Member States have identified four approaches in policy and regulation (Garben, 2017; Eurofound, 2018). The first approach is to simplify existing regulations on online platform work, which often means determining whether the platform worker is an employee, self-employed, or in some cases a third category. This is particularly present in Ireland, the Netherlands, Sweden, and the United Kingdom. On the other hand, in Belgium and Denmark, online platform workers are mostly considered self-employed.

The second approach is to take explicit measures to narrow the group of persons that are considered self-employed. This has been realized through the addition of an intermediate "(independent) worker" category (in the United Kingdom) or a rebuttable presumption of employment (in Belgium and the Netherlands). The analyses and evaluation of the status of online platform workers in these countries confirm these measures do not resolve the categorization difficulties.

The third approach is to decouple the application of existing regulations from the status of employment, thus potentially making employment rights (for instance, concerning minimum wages and social security) and other occupational safety and health rights and rules applicable also to the self-employed (again in the United Kingdom).

Lastly, the fourth approach is to provide specific occupational safety and health and other employment protection measures for online platform workers, regardless of their employment status. This has been realized in France, where independent workers on an online platform can be insured for accidents at work, which is the responsibility of the online platform in question. These workers equally have a right to continue professional skilling and training, for which the online platform is responsible. The platform, at the workers' request, should provide a validation of their working experience. Finally, these workers have the right to form a trade union, to be members of a union, and to have a union represent their interests. They also have the right to take collective action in protection of their interests. 


\section{Platform Work in Croatia}

\section{Terminology}

In Croatia, the most used term regarding platform work is rad preko platformi, a translation of the English words "platform employment." The other common form is platformski radnici, meaning "platform workers." The term used for "sharing economy" is ekonomika dijeljenja. There is no common terminology that is recognized by policy, with legal definitions or connotations. The aforementioned words are used inconsistently on a more ad-hoc basis.

\section{Discussion on Platform Work}

Although relatively many people are active in platform work, such form of activity is not often present in public discussion. There are some sporadic articles on platform work, mostly on online technology magazines or special freelancing websites. Although all stakeholders - primarily employers' and employees' organizations - are informed of such employment possibilities in foreign countries, the discussion of their regulation and development has not yet started in Croatia. Currently, no discussion at the national level has been initiated regarding platform work. Thus, it is not possible to assess the attitudes of stakeholders regarding this issue. However, there are noteworthy articles such as Bjelinski Radić's (2017), where the author explained how new forms of work, particularly platform work, constitute a challenge for labour legislation.

In December 2016, the Institute for Development and International Relations (IRMO) Zagreb held a foresight workshop on the topic of platform economy and platform work. This event (organized as a part of an EU funded project) promoted debate between social partners and independent experts on new digital technologies, platform work, and Industry 4.0. The representatives of the Croatian Employers' Association underlined that the market itself forces them to adapt to the new realities of work. In order to survive, employers in Croatia must develop new brands, which is sometimes only possible through engagement with platform work. On the other hand, the employers' representative describes the public sector (as a market participant) as rigid and not following the trends. All this creates a paradox in Croatia where there are both companies that represent excellent examples of digitalization and modernization and companies that are still only marginally engaged in these processes. Some companies want to play fairly, but they are often defeated by competitors that undermine all working standards. Many such individuals and companies are issuing invoices "in a cloud" and are not paying taxes (Samardžija, Butković, \& Skazlić, 2017).

Currently, there are no national surveys on the widespread use and characteristics of platform work and almost no discussion about specific segments of such work. Uber's entry into the Croatian market opened a discussion on the operating 
conditions of the drivers. However, the discussion was not about working and legal conditions but about the company's ability to satisfy the necessary organizational and administrative conditions in order to be able to carry out the transport service at all.

The trade unions (TU) greatest problem concerning platform work is the absence of legal regulation, which creates chaos in the workplaces. However, the major TU discussions today are focused on the future organization of trade unions, how to organize workers, how to adjust TU activities to such new forms of work, and how to handle collective bargaining in the future (interview with TU representative).

\section{The Regulation of Platform Work in Croatia}

There is almost no regulation, but the development of regulation has started. For platform work, the Labour Act and minimum wage regulation are not applied, neither are rights on yearly holidays or sickness compensation (Muratti, 2016). Currently, there is no information on collective agreements or other sector regulations that consider platform work. Thus, Bjelinski Radić (2017) underlines the need to establish a clear and transparent legal framework that would help develop the new employment forms that emerged through digital technologies.

In January 2018, the Minister of Labour and the Pension System, Marko Pavić, announced that in the second half of the year the Ministry would start a process of adopting the new Labour Act, which will regulate numerous open issues concerning flexible forms of work, such as platform work. He also announced changes in legislation concerning pension insurance, which will better regulate the rights of people in flexible forms of work. However, until April 2019, such activities have not begun.

\section{The Employment Status of Platform Workers}

Most platform workers are freelancers, and while this is not formally determined, it is a rather common practice among these workers. There is almost no variance in platform employment between platform workers who perform online tasks and those who do offline activities. Regulation of platform work as a form of non-standard employment has been a slow process in Croatia. Partially, it is because trade unions mostly have an unreceptive attitude towards all flexible forms of employment. Nevertheless, some new forms have been regulated as a delayed and fragmentary/incomplete reaction to the labour market crisis (Grgurev \& Vukorepa, 2018).

Regarding alternative forms of work in Croatia, a longstanding tradition involves using contracts outside the employment relationship, such as contracts for services or contracts for authors' work. Thus, platform work could be performed via (1) an employment contract (according to the Labour Act), (2) self-employment, or (3) a contract for service (Obligations Act). However, according to the interviews with 
platform workers, they prefer to work in such a non-organized, informal economy because it allows them relatively high earnings and full work flexibility. Some experts predict that, as a consequence of platform economy, the number of self-employed in Croatia will be greatly increased in the next 10 years. This would mean a change of the current trend since self-employed individuals were severely hit by the economic crisis and their number in Croatia has been decreasing since 2010.

Regarding the formal relationship between platform workers and clients, it is mostly determined by the platform. In theory, it can have any contract type: a service contract between the client and the worker, a civil law contract between the platform and the client, or a civil law contract between the platform and the worker. However, the service contract between the client and the worker is the most common. Some platforms have a set of terms and conditions that most users - workers and clients are only partly familiar with. For example, one term may stipulate that clients and freelancers have to do their payments through the platform in order for the platform to also get payment. Failing to do so might lead to the termination of the account, and possibly some kind of legal action. Another aspect of the agreement is that the work performed through the platform is automatically considered work-for-hire (i.e., the copyright belongs to the client rather than the worker). There is also probably some kind of privacy regulation to protect client information. Some clients take this further and ask the freelancer to sign a non-disclosure agreement.

According to Grgurev and Vukorepa (2018), platform work in Croatia is a part of non-standard employment that is often without any social insurance or, at least, without adequate social insurance. Therefore, marginalization in the labour market may lead to marginalization in old age. Namely, in contributory (earnings related) pension schemes of Bismarckian Pay-As-You-Go systems, such as the Croatian mandatory two-tier system, retirement income is mainly linked to past earnings and insurance periods. Hence, more fragmented careers and low incomes may decrease pension entitlements - unless some redistributive (solidarity) mechanisms are developed. In Croatia, pension entitlements related to platform work as a form of self-employment are obtained if self-employed persons pay pension contributions in the amount that is equal to $110 \%$ of the average wage in Croatia.

Previously, work under a contract for service (except for pensioners) attracted compulsory social security contributions, whereas work under an author's contract did not. The Amendments to the Contributions Act adopted on 2 December 2016 abolished this anomaly and reduced unequal treatment by making contributions obligatory in respect of all "other income", regardless of contract type. However, the contribution rate is reduced by one half (e.g., for compulsory first-pillar pension insurance, it is $7.5 \%$, instead of $15 \%$; for the second pillar, it is $2.5 \%$ instead of $5 \%$; and for compulsory health insurance, it is $7.5 \%$ instead of $15 \%$ ). Pension entitlement is based on salary and insurance period. In relation to casual work, the system is notably inconsistent. Namely, contrary to income based on contract for service, income based on an au- 
thor's contract does not entail obligations to any social security contributions. Hence, the total cost for such work is lower, and it does not incur any pension entitlements. The research conducted by Grgurev and Vukorepa (2018) showed that flexible forms of work might have an adverse effect on pension entitlements in two forms. First, in the form of lower pensions and, second, in the form of limited access to some pension rights. Lower pension rights are especially visible in work arrangements connected to lower salaries or minimal contribution base, such as platform employment.

According to Grgurev and Vukorepa (2018), flexible forms of employment are inevitable because there is a social and economic demand for them. However, state measures should be focused on equalising contributions for all sorts of employment, in order to widen the scope of those for whom the pension contributions are being paid. In the near future, it is important to reflect more on state measures, which could be introduced as to avoid the marginalization of workers engaged in flexible forms of employment.

Regarding health insurance, the self-employed have the same entitlements to healthcare as other citizens, and like most of them (with the exception of children under the age of 18 and people suffering from certain diseases) they are subject to compulsory co-payments. Croatian citizens are required to partially participate in health care expenditures through compulsory co-payments, and this requirement is applicable to the self-employed.

On the other hand, Croatian social assistance covers all citizens (a universal system). There are no special provisions for self-employed or non-standard workers compared with standard workers. However, all benefits are means-tested based on income.

An important factor in platform work employment is the issue of taxation. According to the Income Tax Law (OG 177/04, 73/08, 80/10, 114/11, 22/12, 144/12, $43 / 13,120 / 13,125 / 13,148 / 13,83 / 14,143 / 14,136 / 15)$, income from flexible forms of employment can be categorised into the following: (1) employment income, (2) self-employment income, (3) other income, and (4) non-taxable income. Income from casual work based on contract for service is deemed to be "other income."

\section{Voices of Platform Work in Croatia}

\section{Data Collection}

Even though platform work has already become an integral part of Croatian labour markets, not much is known about its functioning. In order to fill the gap, this paper reports the most important findings from qualitative interviews conducted between December 2018 and January 2019 with 20 workers and 8 representatives of relevant institutions - primarily employers' and employees' organizations and the scientific community - in Croatia. Some of the interviews conducted during 2018-2019 were 
face-to-face, while some of them were interviews on internet - a relatively new approach called netnography (Bowler, 2010). Among other important issues, this study aimed to explore the reasons for participation and the strategies participants apply to ensure their successful participation in platform work. Interviews were semi-structured, which enabled us to discuss the most important issues with every single participant while simultaneously allowing them to develop the topics and potentially to provide new aspects of the phenomenon.

\section{Results - Scale and Characteristics}

There are no official data about the scale of platform work, only unconfirmed estimations. According to the interviews with 20 persons active in platform work, the most frequently used platforms in Croatia are foreign, widely used platforms like Upwork. com, freelancer.com, guru.com, and 99design.com, which are characterized by competition and market-like high autonomy. There are some local platforms, such as http://www.predstavljamo.com and www.honorarniposao.net, but they are not often used. The tasks on the platforms mostly require medium-level skills. Most clients are private individuals, but in some cases, the clients are also companies. In most cases, the platform selects the worker, and the service delivery format is usually online provision of services.

The dominant pages are Upwork.com and Fiverr.com (both are international). Useful pages are also Coworking.hr and Freelance.hr. On Upwork, it is easy to search for freelancers from a specific region and to see an estimate of their total earnings through that platform (e.g., search for Croatian freelancers who have earned more than $\$ 1,000)$. There are approximately 400 freelancers from Croatia with at least $\$ 1,000$ in earnings on that platform. In addition, it is possible that some freelancers in Croatia do not list their location as Croatia. For individual freelancers, it is possible to see which projects they worked on, when, and how much they have earned. Such possibility does not exist for Uber drivers, for instance.

\section{The Main Motivations for Platform Work}

Clients engage in different platforms because they are looking to hire cheap labour (assistants, data entry, etc.) at lower rates than they could hire locally or because these platforms offer more flexibility (no payroll taxes and no obligation to offer full-time positions). Others are looking for specialized skills that they could not find locally, that they could not afford otherwise, or that they do not need full-time (e.g., marketing, design, or software development). Additionally, platform employment is sometimes convenient for the clients (companies) if they do not want to show an increase in employment - as such workers are not registered as employed. 
Clients, particularly foreign ones, mostly employ people through online platforms because they can obtain quality and a relatively cheap labour force. For the same job, the cost of a freelancer from Croatia can be five times less than a specialist from the United States. On the other hand, platform work allows Croatians to earn $\$ 1000$ per month - a respectable salary in Croatia, particularly if the worker is not paying total taxes and social contributions. Consequently, online platform work increases international competition. According to economic theory, this will gradually increase salaries in Croatia and decrease salaries in the United States for tasks that can be provided by platform work.

One interviewee, who is fully employed for domaining work on HonorarniPosao. net, explains,

I have chosen domaining as a basic source of income and a "full time job," but it is expected that all beginner domaining will be understood as a part-time job and it is advisable to get started. [Domaining is in any case a part-time job, but the government believes that the name of a part-time job means a "one-on-one" job. Domaining can be a succession but also a basic job.] Those who do not currently have a job can do more domaining work seriously and do it "full time." Work from home gives you more time for your other activities and responsibilities. Even if you want to work eight hours a day, you need at least one hour for home-to-work trips, and those fortunate need only 30 minutes from home to work. When you have a home-based job, you save money on transportation, as well as on food and drinks. On a monthly level, these savings are well noticed.

This informant points out that there are many costs that the employee can save by working from home. These costs are not only pecuniary; commuting time can be viewed as an opportunity cost. The time spent travelling back and forth to the workplace is also worth something, and this "something" is the opportunity cost.

Another directly interviewed person states,

Inever wanted to work in an office or a company. Working in this way [freelance] pays better than any full-time job I could get in an office. Even though I am paid better, I work less than I would at a traditional job. I get to do work that is more interesting - nobody would hire me locally for these kinds of projects or pay these rates. I have flexibility about where I work, when I work, how much I work, and with whom I work.

The informant gives voice to a dissatisfaction with how work life is constructed in Croatia today. With platform work, the informant gets higher flexibility and a higher salary. 


\section{Voices of Platform Work}

Most freelancers work alone from their homes, although more and more coworking spaces are being opened. These spaces allow people that work on similar activities to exchange experiences. Platform workers sometimes use coworking spaces. One of the most used spaces is BIZ Kosnica in Zagreb. It is a platform and a community where one can develop business ventures and projects, meet new clients and customers, and make successful partnerships. This community is made up of an interesting crew: They are creators, leaders, and innovators that make changes. Also popular is HUB385. There are similar places in other Croatian cities: KIWI Creative Space in Rijeka, Amosfera Coworking in Split and COIN in Zadar.

There is no information about a trade union organization of platform workers in Croatia, but there is the Croatian National Coworking Community. It is a programme by the Croatian Independent Professionals Association (CIPA). The initiative was started in the spring of 2012, and the members believe that in a short period they significantly contributed to the promotion of the coworking movement. Nonetheless, they are aware they have a long way to go. Their goal is to participate in opening an NGO-based "freelance coworking centre" in Zagreb, where they encourage and endorse each new coworking space in Croatia. The mission of the Croatian National Coworking Community is to position independent work as an entrepreneurial choice, to advocate independents' rights, and to support professional self-sustainability. The organization encourages opening coworking spaces across Croatia, where independent workers can find "their own" professional place and thus be able to fulfil their regular or temporary work commitments. The Community plans to realize this by providing the support, necessary information, knowledge, and skills required for opening and managing a coworking space and granting access to its community.

\section{Conclusion}

Workers tend to be driven by both push and pull factors to engage in platform work. Currently, platform work is not very widespread in Croatia, but it is expected to grow as motivations to join this form of employment increase. Sometimes, the main motivation to do platform work is the lack of alternative employment opportunities. In other cases, platform work may provide access to labour markets for people living in remote areas or for those who have to stay at home (for example, because of bad health or care responsibilities for a household member). Furthermore, platform work allows people to circumvent some discrimination factors in the traditional labour market. Unemployment motivates citizens to use every opportunity to work, including platform work; indeed, many of the new self-employed, who registered during the Great Recession crisis, have found projects through platforms. However, the main and common motive is the possibility to earn additional income. Nevertheless, one 
should not neglect the importance of flexibility and autonomy: platform work allows workers to achieve work-life balance; to choose their own tasks, work load, work schedules, and place of work; and finally to not work under a superior.

As for clients, information on their reasons to utilize platform work is limited. In some cases, the lack of university graduates in the science, technology, engineering, and mathematics (STEM) fields drives companies to engage with online platforms to access labour beyond the national labour market. Further, online tasks provide an opportunity to recruit talent. At the same time, the access to cheaper or more flexible labour compared to traditional employment is often the driver for platform work.

In a wider perspective, platform work increases international competition because it lowers the transaction costs of labour mobility. Free movement is one out of the four EU freedoms, but so far, it has been less used than the other freedoms. One reason is that it is expensive to move. Platform work decreases the costs of engaging someone from another country. With decreasing transaction costs, international competition increases, which will potentially lead to converging wages.

Bearing in mind the importance of fair working conditions for all workers, in Croatia as well as in the EU, platform workers need to be covered by protections comparable with those of other employees. Another important step is to secure occupational health care for platform workers (with platform workers covering the costs). Finally, it is crucial to include them in social security, primarily to ensure that platform workers have access to unemployment and pension insurance.

\section{NOTES}

${ }^{1}$ http://www.bizkoshnica.biz

${ }^{2}$ https://hub385.com

${ }^{3} \mathrm{http}: / /$ amosferacoworking.strikingly.com

${ }^{4} \mathrm{http} / /$ www.coinzadar.hr

\section{REFERENCES}

Bjelinski Radić, I. (2017). Novi oblici rada kao suvremeni izazov za radno pravo - slučaj Uber. (New form of work as challenges for the labour legislation - The case of Uber). Zbornik Pravnog fakulteta Sveučilišta u Rijeci, 38 (2), 881-905. Retrieved April 8, 2019, from https://hrcak. srce.hr/184335.

Bowler, G. M. (2010). Netnography: A Method Specifically Designed to Study Cultures and Communities Online. The Qualitative Report, 15(5), 1270-1275. Retrieved May 8, 2019, from https:// nsuworks.nova.edu/tqr/vol15/iss5/13.

de Groen, W. P., Kilhoffer, Z., \& Lenaerts, K. (2018). Employment and working conditions of selected types of platform work - National context analysis: Germany. Dublin: Eurofound. 
Eurofound. (2018a). Employment and working conditions of selected types of platform work. Luxembourg: Publications Office of the European Union.

Eurofound. (2018b). Platform work: Public and policy debate, regulatory frameworks and representation in EU Member States. Luxembourg: Publications Office of the European Union.

Florisson, R., Mandl, I. (2018). Platform work: Types and implications for work and employment Literature review, Dublin: Eurofound.

Garben, S. (2017). Protecting Workers in the Online Platform Economy: An overview of regulatory and policy developments in the EU, European Agency for Safety and Health at Work, Luxembourg: Publications Office of the European Union, ISSN: 1831-9343.

Grgurev, I. (2014). New Forms of Employment in Croatia - Country Report Croatia (ed. Bernd Waas), ELLN

Grgurev, I., Vukorepa, I. (2018). 'Flexible and New Forms of Employment in Croatia and their Pension Entitlement Aspects', in: Transnational, European, and National Labour Relations (Eds. Sander, Gerald G.; Tomljenovic, Vesna; Bodiroga-Vukobrat, Nada), Berlin: Springer Verlag.

Kranzberg, M. (1986). "The Information Age: Evolution or Revolution", Economic Impact, Vol. 14, No. 3, pp. 63-70.

Muratti, Z. (2016) Novi oblici zapošljavanja na tržištu rada (New forms of employment on the labour market), Zagreb: Ministarstvo rada i mirovinskog sustava, http://www.mrms.hr/wp-content/uploads/2016/11/5.-Novi-oblici-zapo\%C5\%A1ljavanja-na-tr\%C5\%BEi\%C5\%A1tu-rada-Z.-Muratti.pdf [Accessed: April 8, 2019].

Pesole, A., Urzí Brancati, M.C, Fernández-Macías, E., Biagi, F., González Vázquez, I. (2018). Platform Workers in Europe, EUR 29275 EN, Publications Office of the European Union, Luxembourg, ISBN 978-92-79-87996-8, doi:10.2760/742789, JRC112157, Available at http://publications.jrc.ec.europa.eu/repository/bitstream/JRC112157/jrc112157_pubsy_platform_workers_in_europe_science_for_policy.pdf [Accessed: April 8, 2019].

Pierson, P. (2004). Politics in time: history, institutions, and social analysis. Princeton, N.J.: Princeton University Press.

Potočnjak, Ž. (2014) Najznačajnije novine koje donosi novi Zakon o radu, Hrvatska pravna revija, Vol. 14, No. 9, pp. 57-71.

Samardžija, V., Butković, H., Skazlić, I. (2017) Industrial Relations in Croatia and Impact of Digitalisation on the Labour Market. Zagreb: Institute for Development and International Relations.

Schumpeter, J. A. ([1942] 1992). Capitalism, socialism and democracy. London: Routledge.

Sjöberg, O., (2018). Digital Age Employment and working conditions of selected types of platform work National context analysis, Sweden, Dublin: Eurofound.

Thelen, K. (2004). How institutions evolve: the political economy of skills in Germany, Britain, the United States, and Japan. Cambridge: Cambridge University Press.

Valant, J. (2016). 'Sharing economy: They come in like a wrecking ball', European Parliamentary Research Service At a Glance Note, Available at http://www.europarl.europa.eu/RegData/ etudes/ATAG/2016/581956/EPRS_ATA(2016)581956_EN.pdf [Accessed: April 8, 2019].

Vukorepa, I., Tomić, I., Stubbs, P. (2017). ESPN Thematic Report on Access to social protection of people working as self-employed or on non-standard contracts, European Union, available on http://ec.europa.eu/social/BlobServlet?docId=17687\&langId=en 